\title{
Occurrence of Amblyomma rotundatum Koch, 1844 on Epicrates assisi Machado, 1945 in João Pessoa, Paraíba, Brazil
}

\author{
Ocorrência de Amblyomma rotundatum Koch, 1844 em \\ Epicrates assisi Machado, 1945 em João Pessoa, Paraíba, Brasil
}

\author{
Aksa Ingrid Vieira Batista ${ }^{1 *}$ (1) , Gabriel Vinicius Carvalho de Lucena² (D), Kleber Silva de Oliveira Filho ${ }^{3}$ (1), \\ Thiago Ferreira Lopes Nery ${ }^{4}$ (1), Thiago Fernandes Martins ${ }^{5}$ (D), Josivania Soares Pereira ${ }^{6}$ (c)
}

\begin{abstract}
The Caatinga rainbow boa (Epicrates assisi Machado, 1945) is a snake belonging to the order Squamata, family Boidae, and subfamily Boinae. It has a wide distribution in Brazil and can be found in the Caatinga biome. The present study aims to report the first occurrence of Amblyomma rotundatum on E. assisi in the municipality of João Pessoa, Paraíba State (PB). On March 3, 2020, a tick collection was performed on the dorsal region of the head of an $E$. assisi, which was captive at the Arruda Câmara Zoobotanical Park, João Pessoa-PB. After collecting the tick, it was transferred to a flask containing $70^{\circ}$ alcohol and sent to the Laboratory of Animal Parasitology of the Federal Rural University of the Semi-Arid (UFERSA) for analysis. Identification was done with the aid of a stereomicroscope using a taxonomic key. The result identified this specimen as a nymph of $A$. rotundatum. The occurrence of this tick species on $E$. assisi is reported for the first time and constitutes new data applicable to the ectoparasites that occur in this host species in Brazil.
\end{abstract}

KEYWORDS: Herpetology; Parasitology; Ticks.

RESUMO: A jiboia arco-íris da Caatinga (Epicrates assisi Machado, 1945) é uma serpente pertencente à ordem Squamata, família Boidae, e subfamília Boinae. Esta possui ampla distribuição no Brasil, podendo ser encontrada no bioma Caatinga. O presente trabalho tem como objetivo relatar a primeira ocorrência de Amblyomma rotundatum em E. assisi no Município de João Pessoa, no Estado da Paraíba (PB). No dia 03 de março de 2020, foi realizada uma coleta de carrapato na região dorsal da cabeça de uma E. assisi, que se encontrava cativa no Parque Zoobotânico Arruda Câmara, João Pessoa-PB. Após a coleta do carrapato, este foi transferido para um frasco contendo álcool $70^{\circ}$ e encaminhado ao Laboratório de Parasitologia Animal da Universidade Federal Rural do Semi-Árido (UFERSA) para análise. A identificação foi realizada com o auxílio de estereomicroscópio usando-se chave taxonômica. O resultado identificou o referido espécime como uma ninfa de $A$. rotundatum. A ocorrência dessa espécie de carrapato em $E$. assisi é relatada pela primeira vez e constitui um novo dado aplicável aos ectoparasitos que ocorrem nessa espécie hospedeira no Brasil.

PALAVRAS-CHAVE: Herpetologia; Parasitologia; Carrapatos.

\section{INTRODUCTION}

The Caatinga rainbow boa (Epicrates assisi Machado, 1945), also known as the Caatinga salamant, is a snake belonging to the order Squamata, family Boidae, and subfamily Boinae. It has aglyphous dentition, thus not being a venomous species, and it draws attention due to its iridescent-color scales when exposed to sunlight, since it has ocelli along the back of the body. Epicrates assisi has a wide geographic distribution in Brazil, and is often found in the Caatinga, and has a crepuscular/ nocturnal habit. The species can reach up to two meters in length, feeding on lizards, birds, and small rodents (DE ALMEIDA; SANTOS, 2011).

Ectoparasitoses are among the main diseases that affect captive reptiles, and due to hemophagia, even at low levels of infestation, ticks can transmit several pathogens of medical and veterinary interest, as well as cause the death or paralysis 
of snakes because of the inoculation of toxins during blood repast (DURDEN; KNAPP, 2005; DANTAS-TORRES et al., 2005, 2008; HANSON et al., 2007; DE MELLO, 2013).

In Brazil, 75 species of ticks are found, 51 in the Ixodidae family and 24 in the Argasidae family. Several of these are found as ectoparasites of reptiles, among which there are species classified in the families Ixodidae and Argasidae in the genera Amblyomma and Ornithodoros (PEREIRA et al., 2012; DANTAS-TORRES et al., 2019; MARTINS et al. 2019; MUÑOZ-LEAL et al., 2020; ONOFRIO et al., 2020; SOUZA et al., 2020).

The genus Amblyomma is represented worldwide by 139 species, of which 33 have been registered for Brazil, thus being the most numerous in the country and including the main species that can parasitize humans and transmit pathogens of Public Health importance (KRAWCZAK et al., 2015; MARTINS et al. 2019). Among the reptiles affected by ticks, snakes of the genus Epicrates have already been recorded with infestation by some species of the genus Amblyomma, such as Amblyomma dissimile Koch, 1844 in Epicrates striatus fowleri Sheplan and Swartz, 1974 in the Bahamas (DURDEN; KNAPP, 2005) and Amblyomma rotundatum Koch, 1844 in Epicrates cenchria (Linnaeus, 1758) in Pernambuco, Brazil (CUNHA et al., 2003).

Considering that in Brazil, especially for the Northeast region of this country, the records of occurrence of ticks for reptiles of the genus Epicrates are scarce and sparse, having a long time between one report and another, the present study aims to report the first occurrence of $A$. rotundatum on $E$. assisi in the Municipality of João Pessoa, Paraíba State (PB), which is a captive of the Arruda Câmara Zoobotanical Park.

\section{MATERIAL AND METHODS}

The project was submitted to the Ethics Committee on the Use of Animals in Research of the Federal Rural University of the Semi-Arid (UFERSA) (CEUA-UFERSA) and approved (Opinion No. 11/2020). All handling procedures that the animals were submitted during this research followed the specific guidelines of the committee.

On March 03, 2020, a tick collection was performed, according to Pereira et al. (2012), on the dorsal region of the head of a female Caatinga rainbow boa (E. assisi), 16 years old and score 2 (on the scale where 1 refers to cachexia and 5, obesity) (Figure 1). The animal was a captive of the Arruda Câmara Zoobotanical Park, João Pessoa-PB. The zoo (CNPJ: 08.806.721/0001-03) is registered with the Brazilian Institute of Environment and Renewable Natural Resources (IBAMA) under Registry No. 236567.

To collect the tick specimen, E. assisi was physically restrained with the help of a snake-handling hook with a U-shaped tip. Subsequently, only one collected tick specimen was transferred to a flask containing $70^{\circ}$ alcohol and sent for analysis to the Laboratory of Animal Parasitology at UFERSA
(LPA-UFERSA). Identification was performed with the aid of a stereomicroscope using the taxonomic key of Martins et al. (2010). After inspection and collection of the ectoparasite, the snake was released and kept in its usual enclosure.

\section{RESULTS AND DISCUSSION}

From the analysis of the specimen, it was identified as a tick (a nymph of $A$. rotundatum). The species was confirmed by the presence of two spines on coxa I; two spines, with a very small internal one, on coxa II; and hypostomal formula 2.5/2.5 (Figure 2).

The $A$. rotundatum tick is a widely distributed species in Brazil, abundant in the areas where it occurs and reproduces predominantly by parthenogenesis, although the male has already been described (LABRUNA et al., 2005). The species is mainly native to the Neotropical region of Central and

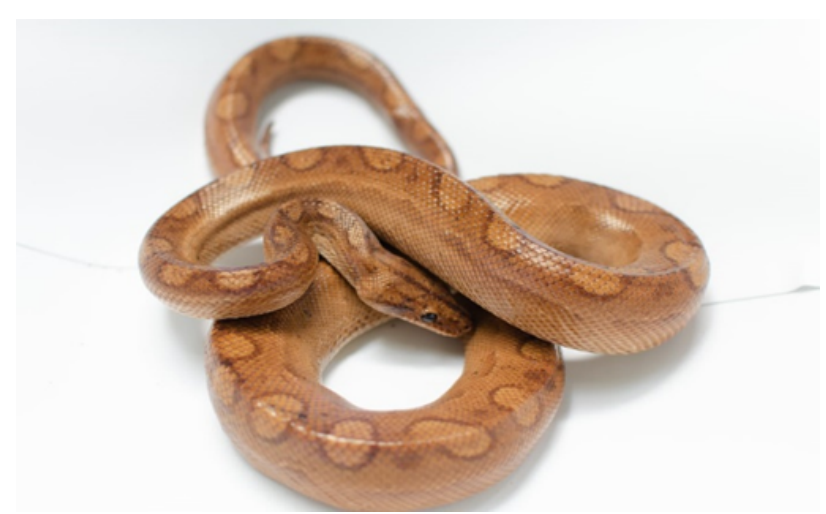

Figure 1. Species of Epicrates assisi MACHADO, 1945 at the Arruda Câmara Zoobotanical Park, João Pessoa-PB.

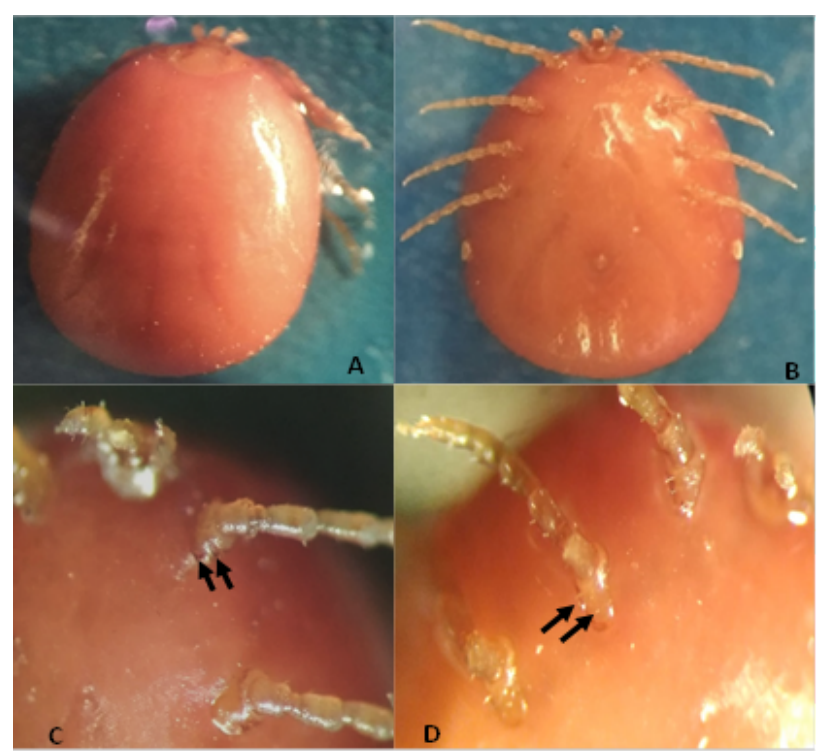

Figure 2. Nymph of Amblyomma rotundatum KOCH, 1844 (objective 5.6x): A- Dorsal view; B- Ventral view; C- Coxa spines I; D- Coxa spines II. 
South America; however, the tick has been described for the Nearctic region. Thus, the common hosts for these ticks are Anura: Bufonidae and Squamata: Boidae, with crocodilians and mammals being considered exceptional hosts for this ectoparasite (DE MELLO, 2013; GUGLIELMONE et al. 2014).

Of the 33 Amblyomma species already reported in Brazil, only four are frequently recorded in amphibians and reptiles in the country: A. dissimile; Amblyomma fuscum Neumann, 1907; Amblyomma humerale Koch, 1844. and A. rotundatum. This genus is virtually found in all Brazilian states, with records of infestation on snakes. As examples, we can mention: A. rotundatum on Boa constrictor constrictor in Rio Grande do Norte (PEREIRA et al., 2012); A. dissimile on Eunectes murinus, in Pará (DO NASCIMENTO et al., 2017); and Amblyomma sculptum Berlese, 1888 - published as Amblyomma cajennense (Fabricius, 1787) on Crotalus durissus, in Goiás (SZABÓ et al., 2007). The species $A$. dissimile and $A$. rotundatum are the most common ectoparasites of amphibians and reptiles, both distributed in the Neotropics and highly adapted to anthropic environments (DANTAS-TORRES et al. 2008, 2010; GUGLIELMONE et al., 2014; MORAIS et al., 2017; DE ALCANTARA et al., 2018; ODA et al., 2018; SOUZA et al., 2020).

Considering the genus Epicrates in Brazil, the occurrence of $A$. rotundatum infestation on these reptiles has been reported only once, on the species Epicrates cenchria, in the State of Pernambuco (CUNHA et al., 2003). In the same decade, Dantas-Torres et al. (2010) conducted a research with captive animals in a Zoobotanical Park in Pernambuco and also in the same zoo where the present research was conducted, the Arruda
Câmara Zoobotanical Park in Paraíba, where they recorded the occurrence of nymphs of Amblyomma spp for E. cenchria.

Thus, after 17 years, the present work records the occurrence of $A$. rotundatum in the genus Epicrates in Brazil and records the occurrence of the Ixodidae $A$. rotundatum in the host species $E$. assisi for the first time.

\section{CONCLUSION}

The occurrence of $A$. rotundatum on $E$. assisi is reported for the first time and constitutes new data applicable to the ectoparasites that occur in this host species in Brazil. This meeting contributes to the expansion of ecological data, as well as to the conservation of this Boidae. From the present study, future work can be carried out with the aim of understanding the bioecology of these ectoparasites in rainbow boas from the Caatinga and investigate the consequences that the populations of these hosts may suffer in the wild and how the relationship of $A$. rotundatum interferes with the welfare of the host species in captivity.

\section{ACKNOWLEDGEMENTS}

We are grateful to the Federal Rural University of the SemiArid (UFERSA) for the support in the development of this research and to the researchers of the Laboratory of Animal Parasitology (LPA-UFERSA). We would also like to thank the entire team at the Arruda Câmara Zoobotanic Park, in João Pessoa-PB, which unfortunately not all were able to enter as co-authors of this article, but were essential for its realization, both in terms of availability and in the willingness to help in various stages of the study.

\section{REFERENCES}

CUNHA, M. C. A. L. et al. Intensidade de parasitismo de Amblyomma rotundatum Koch, 1844 (Acari: Ixodidae) em serpentes da Família Boidae capturadas no Parque dois Irmãos, Recife, Pernambuco, Brasil. Entomología y Vectores, v. 10, n. 1, p. 21-29, 2003.

DANTAS-TORRES, F;; OLIVEIRA-FILHO, E.F.; SOUZA, B.O.F; SÁ, F.B. First record of Amblyomma rotundatum Koch, 1844 (Acari: Ixodidae) parasitizing Crotalus durissus cascavella (Wagler, 1824) (Squamata: Viperidae) in the State of Pernambuco, Brazil. Arquivos do Instituto Biológico, v. 72, п. 3, p. 389-390, 2005.

DANTAS-TORRES, F. et al. Ticks infesting amphibians and reptiles in Pernambuco, northeastern Brazil. Revista Brasileira de Parasitologia Veterinária, v. 17, p. 218-221, 2008.

DANTAS-TORRES, F. et al. Ticks on captive and free-living wild animals in northeastern Brazil. Experimental and AppliedAcarology, v. 50, p. 181-189, 2010.

DANTAS-TORRES, F. et al. Ticks (Ixodida: Argasidae, Ixodidae) of Brazil: updated species checklist and taxonomic keys. Ticks and tick-borne diseases, v. 10, n. 6, 2019.
DE ALCANTARA, E. P. et al., Ticks (Acari: Argasidae and Ixodidae) infesting amphibians and reptiles in Northeastern Brazil. Systematic and applied Acarology, v. 23, n. 8, p. 1497-1508, 2018.

DE ALMEIDA, G. V. L.; SANTOS, E.M. A Salamanta (Epicrates assisi Machado, 1945) é um animal venenoso - Percepção de algumas comunidades do sertão de Pernambuco. João Pessoa: Editora Universitária da UFPB, 2011.

DE MELLO, E. M. Endo e ectoparasitos de serpentes Crotalus durissus Linnaeus, $\mathbf{1 7 5 8}$ (Viperidae) de algumas localidades de Minas Gerais. Belo Horizonte: UFMG. 2013.

DO NASCIMENTO, K. K. G. et al. Tick fauna of wild animals received and attended at the Santarém Zoological Park, western Pará State, Brazil. Ciência Rural, v. 47, n. 10, 2017.

DURDEN, L. A.; KNAPP, C. R. Ticks parasitizing reptiles in the Bahamas. Medical and Veterinary Entomology, v. 19, n. 3, p. 326-328, 2005.

GUGLIELMONE, A. A. et al. The hard ticks of the world (Acari: Ixodida: Ixodidae). New York: Springer, 2014. 
HANSONB. A. et al. Tick Paralysis of a Snake Caused by Amblyomma rotundatum (Acari: Ixodidae). Journal of Medical Entomology, v. 44, n. 1, p. 155-157, 2007.

KRAWCZAK, F. S. et al. Amblyomma yucumense n. sp. (Acari: Ixodidae), a parasite of wild mammals in southern Brazil. Journal of Medical Entomology, v. 52, n. 1, p. 28-37, 2015.

LABRUNA, M. B. et al. First report of the male of Amblyomma rotundatum (Acari: Ixodidae) from a field-collected host. Journal of Medical Entomology, v. 42, n. 6, p. 945-947, 2005.

MARTINS, T. F. et al. Nymphs of the genus Amblyomma (Acari: Ixodidae) of Brazil: descrip-tions, redescriptions, and identification key. Ticks Tick-Borne Diseases, v. 1, p. 75-99, 2010.

MARTINS, T. F. et al. A new species of Amblyomma (Acari: Ixodidae) associated with monkeys and passerines of the Atlantic rainforest biome, Southeastern Brazil. Ticks and Tick-Borne Diseases, v. 10, 2019.

MORAIS, D. H. et al. Patterns of parasitismo by Amblyomma humerale (Acari: Ixodidae) on Chelonoidis denticulatus (Testudines: Testudinidae) in the Brazilian Midwest. Herpetological Review, v. 48, п. 2, p. 316-319, 2017.
MUÑOZ-LEAL, S. et al. Ornithodoros cerradoensis n. sp. (Acari: Argasidae), a member of the Ornithodoros talaje (Guérin-Méneville, 1849) group, parasite of rodents in the Brazilian Savannah. Ticks and Tick-borne Diseases, v.cll, 2020.

ODA, F. H. Amblyomma species infesting amphibians and reptiles in the seasonally dry Amazon forest, with new host records for Amblyomma rotundatum (Acari: Ixodida: Ixodidae). Systematic and Applied Acarology, v. 23, n. 2, p. 387-392, 2018.

ONOFRIO, V.C. et al. Description of a new species of Ixodes (Acari: Ixodidae) and first report of Ixodes lasallei and Ixodes bocatorensis in Brazil. Ticks and Tick-borne Diseases, v. 11, p. 101423, 2020.

PEREIRA, J. S. et al. Infestação por carrapatos em Boa contrictor constrictor (Linnaeus, 1758) de cativeiro, em Mossoró, Rio Grande do Norte. Revista Brasileira de Zoociências, v. 14, n. 1, 2, 3, 2012.

SOUZA, V. L. et al. Infestation of free-ranging reptiles by ticks of the genus Amblyomma (Acari: Ixodidae) in the state of Acre, western Brazilian Amazon. International Journal of Acarology, p. 1-5, 2020.

SZABÓ, M. P. J. et al. Tick fauna from two locations in the Brazilian savannah. Experimental and Applied Acarology, v. 43, n. 1, p. 73, 2007. 